\title{
ADMINISTRATIVE AGENCIES UNDER FIRE
}

\section{Wayland H. Elsbree $\dagger$}

The legal jargon of the day continues to be embellished by the phrase "administrative absolutism." 1 Bar associations are exhorted to stop its growth. Legisiative committees are urged to initiate measures to curb its spread. The legal profession is warned that the adoption of unconstitutional doctrines by administrative agencies threatens to produce a bureaucracy that will destroy it; at the same time, it is informed that administrative law now and in the future offers the greatest opportunity for the practitioner.

What occasion is there for this beating of the drums? Specifically, what agencies are indulging in unconstitutional practices or encouraging the spread of unconstitutional doctrines? What are those practices and doctrines and, if they are being indulged in, have our courts no power under existing law to protect the rights of persons threatened thereby? What remedy do the critics propose and is it sound? If not, is there any program upon which sincere advocates for improvement in the functioning of such agencies can unite?

It is the purpose here to point out briefly:

(I) That criticism of practices followed by administrative agencies should be specific instead of being couched in terms of generalities and should indicate wherein the appropriate courts of review are powerless to prevent the abuses complained of.

(2) That the remedy frequently proposed by some outspoken critics, namely, an all-inclusive code of practice and procedure for federal administrative agencies is unworkable, and has been rejected after a careful, comprehensive study by an eminent committee of lawyers.

(3) That the report of the Attorney General's Committee on Administrative Procedure presents a sound program for orderly improvement in the functioning of these agencies and the legal profession should support the committee's recommendations.

It is unfortunate that critics most outspoken in their denunciation of excesses allegedly perpetrated by administrative agencies often speak in such terms of generalities that one searching their charges in the hope of tracing the evils to a particular source is left without a clue.

† A.B., r921, Swarthmore College; L.L.B, I924, Harvard University; formerly Regional Attorney, Office of Price Administration; member of the Philadelphia Bar.

I. The concept of a society in which there are no laws but only administrative orders; where law is whatever is done officially, so whatever is done officially is law, and beyond criticism. See Pound, For the "Minority Report" (I94I) 27 A. B. A. J. $664,678$. 
We are told that the tangled mess of administrative tribunals should receive some attention, that all administrative agencies have a tendency to go beyond or outside the statute creating them, to adjudicate matters without a hearing or without hearing one of the parties, and to make administrative rules exceeding statutory authority. Such a sweeping indictment surely deserves to be documented. One may inquire what basis there is for asserting that the Interstate Commerce Commission, for example, has a tendency to go beyond or outside its statutory authority in performing its functions. One might inquire, likewise, of any number of agencies less venerable. It is hardly a sufficient answer to point to particular cases where courts of review have held statutory authority was exceeded by agency tribunals. It is no more accurate to claim a tendency on the part of all agencies to exceed their authority because reviewing courts sometimes reverse them, than it is to assert that all courts of first instance have a tendency to exceed their authority because they are sometimes reversed by appellate courts for improper construction of their functions. 'Examination of the digests back through the years will reveal a substantial number of instances wherein judicial review has been necessary to protect private rights threatened by a lower court's disregard for fundamental justice. Such fact, however, does not support the charge that courts of original jurisdiction habitually have abused their powers at the expense of private rights.

Another criticism to be leveled at the critics is their failure to indicate why existing judicial review powers are inadequate to enable the appropriate court to correct the excesses of which they complain. If the constitutional requirements of fairness in the matter of notice and hearing before adjudication are ignored, if decisions are based on rules made in excess of statutory authority or on evidence not made a part of the record, certainly these are matters into which a reviewing court will inquire. ${ }^{2}$

Clearly falling within the scope of judicial scrutiny are a wide variety of issues which the courts choose to call questions of law,

2. "On the procedural side are all the requirements of fairness derived from the Constitution and statute-requirements which, if not met, may, as in the Morgan cases [Morgan v. U. S., 298 U. S. 468, 56 Sup. Ct. 906,80 L. Ed. 1288 (1936); 304 U. S. I, 58 Sup. Ct. 773, 82 L. Ed. 1129 (1938); 304 U. S. 23, 58 Sup. Ct. 999, 82 L. Ed. II35 (1938) ], invalidate administrative action without inquiry into the merits of the results reached by the administrative body. Are notice and hearing prerequisite to the validity of the administrative action? If so, what kind of notice and what kind of hearing? Before whom may the hearing be held and by whom must the administrative determination be made? Was the aggrieved party given proper opportunity to present relevant evidence and to contest evidence used by the agency? Is the administrative decision required to be based only on evidence of record, and, if so, did the agency take into consideration evidence not made part of the record? Is the agency required to formulate findings as a basis for its action and, if so, did it properly make the required findings? These are questions which the court may ask on review and the answers to which may determine the validity of the administrative action." Final Report of the Attorney General's Committee on Administrative Procedure (I941) 88. 
including questions of statutory interpretation as well as questions relating to the constitutional authority of Congress to authorize the action taken by the agency. Failure to specify in what respects the alleged excesses are not subject to judicial check supports the conclusion either that the evils complained of are not as serious as the reformers claim or else that the courts are not conscientiously discharging their functions of review, an assumption hard to support. ${ }^{3}$

Without a "Bill of Particulars" to support their indictment, the critics propose as a remedy a prescription so all-inclusive as to raise grave doubts of its efficacy to cure any existing evils, not to mention the likelihood of its creating new ones. In short, they would have Congress enact a code of administrative procedure for all federal agencies.

Any proposal for federal legislation to provide for uniform rules of practice or procedure for such agencies will certainly bear careful study in the light of the Final Report of the Attorney General's Committee on Administrative Procedure. ${ }^{4}$ This report, representing two years of intensive study by a distinguished committee of lawyers, of those federal agencies entrusted with the power to determine private rights and obligations as of the time the study was made, I939-194I, is a comprehensive survey of practices and procedures existing in those agencies. In rejecting the proposal for a uniform code made by a minority of the Committee, the majority members cogently point out that omnibus legislation prescribing uniformity in the principle and practice of the wide variety of agencies studied by the Committee, results either in mere hortatory provisions, or commanding the obvious, or laying down specific requirements certain to be harmful to some agencies. $^{5}$ The variety of functions they perform is an outstanding characteristic of the agencies looked at as a whole; hardly less noteworthy is the great variety of duties entrusted to each of a number of them. ${ }^{6}$

3. One able critic who supports his charges with some degree of particularity apparently concedes that provision for judicial review by a simple appeal instead of by the cumbersome method of a bill in equity to enjoin enforcement of an illegal administrative order as is now necessary in some cases, would be an effective protection to individuals affected thereby. See Pound, note I supra, at 664, 67I. This writer agrees that review by appeal rather than by injunction is desirable in cases where no statutory review is provided or where the remedy provided by the statute is inadequate to safeguard constitutional or common law rights. But the criticism is valid only insofar as it pertains to the form of review procedure and not the scope of review.

4. Copies of this report may be obtained from the Superintendent of Documents, Washington, D. C., for fifty cents.

5. Final Report of the Attorney General's Committee on Administrative Procedure (194I) I9I-192.

6. "No single fact is more striking in a review of existing federal administrative agencies than the variety of the duties which are entrusted to them to perform. This is true of many single agencies taken alone; it is true above all, of the agencies taken 
Advocates of a universal panacea taking the form of an over-all code would hardly suggest a similar prescription for the various courts embraced in our judicial system, yet the analogy is not far fetched. ${ }^{7}$

However, objections to an over-all code did not prevent the Committee from seeing the need for greater uniformity in some particulars and for suggesting improvements. Accordingly, it made a number of recommendations, some of which were specific, applying to particular agencies, and others of which were general. Its general recommendations were in large part embodied in a bill proposed for Congressional enactment. The four main features of this bill embrace the creation of an Office of Federal Administrative Procedure, a permanent agency to be devoted to the study and co-ordination of administrative procedures for the purpose of achieving improvements that could not be possible through omnibus legislation; provision for publication of proposed rules in advance to give parties affected an opportunity to be heard in the rule-making process; creation of hearing commissioners to improve the adjudication process; and, finally, authorization for the issuance of binding, declaratory rulings to aid interested parties seeking authoritative statements of their rights and duties. ${ }^{s}$

The Committee's proposals deserve more consideration from the legal profession than they have received to.date. ${ }^{9}$ There may be valid criticism of details, but, in the main, the suggestions stand out as eminently sound and point the way to substantial improvement in the future.

as a group. This central and inescapable fact makes generalization in description difficult. It makes even more difficult generalization in prescription. For variety in functions means variety in the circumstances and conditions under which the activities of the various agencies impinge upon private individuals. A procedure which would be for the protection of the individual in one situation may be clearly to his injury in another. A set of standards evolved to meet one problem may fail wholly to meet another. One need look no further than a single agency-the Interstate Commerce Commission-to be impressed by the basic necessity of differing procedures for different types of activities, and by the varying procedural patterns which the Commission has evolved to meet this necessity." Final Report of the Attorney General's Committee on Administrative Procedure (I94I) 20.

7. "To comprehend administrative agencies under uniform rules of practice is like adopting one set of uniform rules for all the range of courts in a state judicial system -police, municipal, small claims, domestic relations, county, criminal, intermediate appellate and appellate." Feller, Administrative Law Investigation Comes of Age (I94I) 4 I COL. L. REV. 589, 615.

8. Final Report of Attorney General's Committee on Administrative Procedure (I94I) I9I-202.

9. Three years have elapsed since the Committee completed its report. Following its issuance it was the subject of much comment and debate in law journals. The American Bar Association by resolution of its House of Delegates, approved the bill drafted by the minority members of the Committee providing for an over-all code standards of fair administrative procedure. 66 Annual Report A. B. A. 40I (I94I). This bill as well as the bill proposed by the majority of the Committee members has been referred to a sub-committee of the Senate Judiciary Committee, but neither measure has been reported out. 
Undoubtedly a great deal of current criticism is directed against those agencies created or empowered since the date of the Committee's report to discharge duties necessary to the prosecution of the war. The War Production Board, the War Labor Board and the Office of Price Administration, to name a few of them, are empowered in the interest of national defense to impose drastic curbs upon economic activities at all levels. Price fixing, wage fixing, rationing and priorities are, for the time, accepted as a part of everyday living. But these controls have engendered tremendous counter-pressures. It was, therefore, to be expected that charges of abuse of authority, bureaucratic methods, and unreasonable interference with individual rights and liberties would be leveled at these agencies. In the present world conflict, the choice was between chaos and curtailment of peacetime economic liberties. As soon as their purposes are served it may be expected that these controls will be lifted, and with their passing much of the clamor of the day will cease. Contrary to the charges leveled against them, however, it may be pointed out that the agencies concerned have striven to insure the preservation of traditional concepts of fair play in their use of techniques to obtain compliance with wartime regulations.

For example, a very effective sanction used by the Office of Price Administration in the rationing of scarce commodities is the issuance of a rationing suspension order. ${ }^{10}$ Since experience with this administrative sanction has proved its success as an enforcement device and since the procedure set up for its operation follows so far as is presently practical one of the main recommendations of the Attorney General's Committee, relating to the creation of hearing commissioners, it deserves a brief description. An Office of Administrative Hearings was established within the agency consisting of a hearing administrator in the national office, and a chief hearing commissioner, hearing commissioners, and presiding officers in each regional office. The hearing administrator is authorized to employ and discharge hearing commis-

I0. The statutory basis for the authority to ration is found in Section 2 (a) of "An Act to Expedite National Defense, and For Other Purposes," 54 STAT. 676 (1940), as amended by 55 STAT. 236 (I94I), and by Title III of the Second War Powers Act, 56 STAT. $176,178,180$ (1943). The pertinent language of that Section is as follows:

"Whenever the President is satisfied that the fulfillment of requirements for the defense of the United States will result in a shortage in the supply of any material or of any facilities for defense or for private account or for export, the President may allocate such material or facilities in such manner, upon such conditions and to such extent as he shall deem necessary or appropriate in the public interest and to promote the national defense."

The Act further provides, Sec. 2 (a) (8), that "The President may exercise any power, authority, or discretion conferred on him by this subsection (a), through such department, agency, or officer of the Government as he may direct and in conformity with any rules or regulations which he may prescribe." By Order approved by the President, authority to ration at the retail or consumer level was vested in the Office of Price Administration (dated January 24, 1942, 7 F. R. 562). 
sioners and presiding officers and he supervises their activities throughout the country. He also decides appeals from decisions of the commissioners and his decisions are unreviewable except by the courts. ${ }^{11}$

- A proceeding for the issuance of a suspension order is instituted by the service of notice of hearing upon the respondent. Notice must be served at least three days in advance of the hearing, must designate the time and place, must contain a statement of the charges against the respondent and a statement of the purposes for which the hearing is to be held.

The hearing, presided over by a hearing commissioner or a presiding officer, must be public. ${ }^{12}$ The hearing commissioner is empowered to administer oaths, issue subpœnas, and rule upon motions. Respondent has the right to be represented by counsel and is afforded reasonable opportunity to cross-examine witnesses. While rules of evidence prevailing in courts of law or equity are not controlling, the issuance of a suspension order must be based upon substantial evidence of a violation. A stenographic report of the hearing is taken. If the hearing commissioner determines that the respondent has violated a rationing regulation, he may issue a suspension order which must set forth findings of fact and conclusions of law upon which it is based, and contain a statement of the reasons for its issuance. If the commissioner determines that no suspension order should be issued, he must similarly set forth his findings and conclusions, with a statement of his reasons. Either respondent or the regional attorney for the price administrator may appeal from the commissioner's order to the hearing administrator, and the latter is empowered to stay the operation of the order pending determination of the appeal. He may also review any case on his own motion if neither party appeals from the order of the hearing commissioner.

This procedure has demonstrated its workability in a large number of cases wherein dealers in rationed commodities have been charged with the violation of rationing regulations. A great majority of the

Ir. The hearing administrator, the chief hearing commissioners and hearing commissioners are all attorneys. While legal training may not be an indispensable qualification for adjudicators in all formal proceedings, a scrupulous observance of fair play in the conduct of hearings and expertness in the fact-finding process are most essential objectives for which the lawyer, by training, is fitted to strive.

12. Hearings may be conducted by a hearing commissioner or a person designated by him as a presiding officer. The presiding officer must prepare an advisory report containing the findings of fact, conclusions of law and recommendations with respect to the disposition of the case which he files with the hearing commissioner and the parties. The use of presiding officers for hearing purposes has been very limited. In practice it proves to be time-consuming and cumbersome. The jurisdiction of local War Price and Rationing Boards to issue suspension orders is limited to certain types of violations by consumers. Their jurisdiction in those instances is concurrent with that of the hearing commissioners. Appeals from orders of the boards are heard by the hearing commissioners. 
cases have been disposed of at the hearing commissioner level. ${ }^{13}$ Where a violation is established the respondent's right to buy as well as to sell commodities rationed under the regulation violated is subject to suspension. This practice accords with the theory basic to the issuance of suspension orders-that persons who divert scarce commodities from essential civilian or military use in violation of the rationing regulations interfere with the administration of the rationing program-the purpose of the order is not to penalize the violator but to correct an improper diversion in the flow of such commodities caused by their misuse. $^{14}$

Two things should be observed about this procedure. First, it offers an expeditious and effective way of obtaining compliance and it is flexible in that the period of suspension as well as its scope can be adjusted to the circumstances of each case. Operation of the suspension order against suppliers of the respondent also tends to make for ready compliance. Second, it is impartial in its operation in that the aim is to preserve a complete separation of prosecution from adjudication functions. The Office of Administrative Hearings is not responsible for the success or failure of enforcement attorneys in the Office of Price Administration in obtaining the issuance of suspension orders. Consultation or discussion between enforcement attorneys and hearing commissioners with respect to any suspension order proceeding, prior to hearing or thereafter, in the absence of respondent or his counsel, is abjured.

Experience with this procedure to date supports the conclusion of the Attorney General's Committee that impartiality in adjudication can be achieved by an internal separation of the functions of judging and prosecuting, without complete separation involving the creation of another agency to perform one of them. A personnel trained in the tradition of fairness is a far better safeguard against bias than any

13. Up to October I, 1943, approximately 6,856 suspension order proceedings had been instituted. Exact figures as to the number of appeals are not available, but approximately I0\% of the cases in which suspension orders are entered are appealed.

14. The validity of the suspension order proceeding was upheld in Perkins v. Brown, 53 F. Supp. I76 (D. C. Ga. 1943). Contra: Wilemon v. Brown, 51 F. Supp. 978 (D. C. Tex. 1943); Simon Hardware Company v. Nelson, 52 F. Supp. 474 (D. C. D. C. I943). It may be noted that judicial review in these cases was by the familiar non-statutory remedy of a bill in equity to enjoin enforcement of the suspension order. The Committee of the House of Representatives investigating executive agencies has charged that OPA obstructs "in every way possible judicial review of decisions of the Hearing Administrator." See Second Intermediate Report of the Select Committee to Investigate Executive Agencies (1943) I5. This charge is baseless. Obviously, the OPA has no more power to obstruct judicial review by a bill for injunction to restrain enforcement of a suspension order alleged to be without statutory warrant than any other government agency in the same situation, and to say that any agency is obstructing judicial review by defending in court its authority to issue the order complained of is a gross misuse of lanaguage. L. P. Steuart \& Bro. v. Bowles, I ro Leg. Int. 583, col. 4 (May 23, 1944); affirming, 140 F. (2d) 703 (C. C. A. D. C., I942). 
mechanical safeguard that complete separation would provide, quite apart from other factors that weigh against the latter.

One is mindful of the adage that criticism is a healthy thing; however, moral generalizations lose their glow if they do not illuminate specific evils. Indiscriminate condemnation of administrative agencies may reflect an emotional reaction of the critic rather than a conviction based on any personal knowledge of unfair treatment. Straitjackets and shotguns may subdue the unruly, but the necessity for the use of either instrument is a sure sign of an unregenerate. To suggest that administrative agencies in general have reached a pathological state calling for radical treatment is to confess that they have failed to perform adequately the functions entrusted to them by Congress, a confession that will hardly stand the light of day. ${ }^{15}$ While most of the criticism of administrative procedure appears to be aimed at formal adjudication, the great bulk of the work of the agencies is handled by informal procedure, a fact too often overiooked. ${ }^{16}$

Admitting that improvement in methods of informal adjudication employed by the various agencies is a continuing need, that aim can best be achieved by creation of some permanent body such as an Office of Federal Administrative Procedure charged with the duty of studying and making recommendations to the agencies concerned. By specific treatment of this sort, we can hope for sustained, orderly progress in administrative procedure.

I5. "The Committee has found in its investigation of the administrative process few instances of indifference on the part of the agencies to the basic values which underlie a fair hearing. Perhaps in some measure because of the recent emergence of public and judicial interest in administrative hearings, agencies have in many instances exhibited a healthy self-criticism and considerable alertness to fulfill not only the letter of the judicial pronouncements by the basic implications of fairness in hearing." Final Report of the Attorney General's Committee on Administrative Procedure (I94I) 624.

I6. "In the first four years of its existence the National Labor Relations Board closed 12,227 unfair labor practice cases, in only $8 \%$ of which were formal complaints issued and in only $4 \%$ of which were formal decisions made." Of 3.500 demurrage complaints filed with the Interstate Commerce Commission over a ten year period, settlements were arranged in all but five. See Final Report of the Attorney General's Committee on Administrative Procedure (1941) 35. 